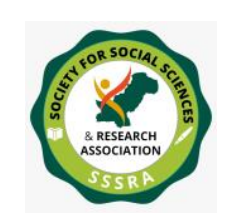

\title{
PUBLIC DIPLOMACY BETWEEN PAKISTAN AND INDIA: AN ANALYSIS
}

Saeed Khan, Research Scholar, Department of International Relations, Federal Urdu University, Karachi

Amna Ameer Ali, Research Scholar, Department of International Relations, Federal Urdu University, Karachi (aamnaameer@ hotmail.com)

\begin{abstract}
Pakistan and India are known as great rival countries with a bitter past. There is a huge historical background of both countries. Infact, several wars have been fought between Pakistan and India, so the diplomatic relations between Indo-Pak are influenced by the number of political and historical events. But both countries tried so hard to maintain peace and there are some examples of these efforts. It is very important for both countries to maintain good relations because geopolitically Pakistan and India are considered as major states for natural resources in the region of South Asia. The whole world sees both countries as great rivals, but before making any decision there are a lot of perspectives which we need to examine carefully. This paper will explain some of the major events of diplomatic relations between Pakistan and India.
\end{abstract}

KEYWORDS: Pakistan, India, Diplomacy, War, South Asia

\section{INTRODUCTION}

Pakistan and India are two neighboring states, both fully equipped with nukes but unfortunately, they never sustained the durable, friendly and long lasting peaceful relation with each other. The reason behind that situation is disbelief and mistrust between these two arch rivals. So far, four wars have been fought between India and Pakistan and this is the root cause of uncertainty among both countries. War is not a solution of any dispute in the world especially in this case of Pakistan and India because both are less developed and third world countries that suffered casualties and gave heavy loss to the economy Because of this twg of war Pakistan 


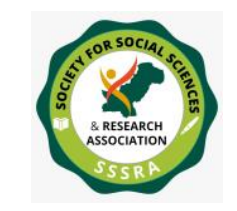

Pak. Journal of Int'L Affairs, Vol 2, Issue 1 (2019)

Public Diplomacy between Pakistan...

and India are far behind the "developed countries". And from fast developing countries such as China, South Africa, South Korea, Malaysia, Singapore etc., hundreds of millions of people of Pakistan and India are leading their life below the poverty level, due to which their living standard is very low as compared to the citizens of European countries and other civilized western states. Geopolitically, Pakistan and India are considered two major states in terms of natural resources and man power in the region of South Asia. The nature of relations between these two rival states have been different from time to time. Sometimes the relations were pleasant enough that the leadership of both states enjoyed the cricket matches together in India's cricket ground for instance Zia-Ul-Haq and Rajiv Gandhi, Pervez Musharraf and Manmohan Singh, Gilani and Manmohan Singh. On the other hand sometimes, relations have been so critical that both states found themselves on the edge of the war, once in 2001 and 2008. Whenever tension eased between Pakistan and India, the reason was always public diplomacy or citizen diplomacy. This form of diplomacy is all about engagement of citizens of a country with the government of other country. In other words, one can say government to public diplomacy, and history illustrates that this kind of diplomacy has always been effective and productive.

Track two diplomacy have been practiced in Indo-Pak such as, cricket diplomacy, cultural diplomacy, pilgrimage diplomacy, treatment of patients and visits of religious sites etc. In this article we will analyze citizen diplomacy and view its effects on politics and Pakistan India relations. One would not have to go deep in the past. Lahore declaration between Pakistan and India was signed in February 1999 when Indian PM Vajpayee visited Lahore to build friendly relations with Pakistan. This was a historic moment for both states to be friendly neighbors and supported each other in crisis but unfortunately both could not cash on this golden chance and soon after the Lahore declaration the "kargil war" out broke which spoiled the whole peace process, and the tension on the borders of Indo-Pak was again on high level. This article is all about "public diplomacy between Pakistan and India". Which took place after Lahore declaration 1999 and it proved fruitful on different occasions. We will look at the incidents that occurred in this span of time. On 12, October 


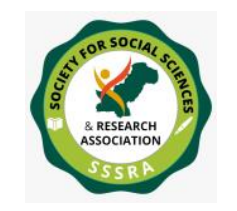

Pak. Journal of Int'L Affairs, Vol 2, Issue 1 (2019)

Public Diplomacy between Pakistan...

1999, the relations between India and Pakistan were totally suspended. Prior to this in January 1999 Indian government had permitted their cricket team to participate in first "Asia Test Championship" to be held in Pakistan, India, Sri Lanka and Bangladesh commonly. This was a good will gesture by the all South Asian states. Pakistani cricket team played the Pepsi one day cup series in India in April 1999 in the meantime things started to get worst on the borders between India and Pakistan. Islamic extremist groups were attaining power in Pakistan and Nawaz Sharif's government was weakening by every passing day. Friendship bus service and cricket diplomacy could not succeed longer, and soon after, the Pakistani and Indian forces were face to face on kargil and dras sector. War out broke between India and Pakistan to occupy the kargil hills. 5 years later in Musharraf's regime Indian PM Vajpayee visited Pakistan in 2004 to participate in SARK conference. Things started to get better after Vajpayee's visit, between two neighboring states. After this visit India allowed its cricket team to tour Pakistan for a complete series.

\section{PUBLIC DIPLOMACY THROUGH CRICKET}

When PM Vajpayee called on Nawaz Sharif in New York on September 1999. Bus service between Lahore and Delhi was suggested in that meeting and secondly, tour of Pakistani cricket team to India was scheduled in February 1999, for two test matchs and unexpectedly Indian fans gave Pakistani team standing ovation on their victory. This was something very special for not only Pakistani players but Pakistani government and public as well. Cricket diplomacy has always been successful too between India and Pakistan, since cricket is very popular in subcontinent, and loved by millions of people in this region. This diplomacy has helped to bring the people of India and Pakistan together. In 2004 when Indian cricket team toured Pakistan, red carpet was unrolled for Indians. Pakistani government and masses gave Indians a very warm welcome. Cricket lovers in Pakistan loved Indian cricket players, and Indian spectators, who came all the way from India to watch the cricket matches and witness these historical moments. Friendship was made between the Indians and Pakistanis in those matches. That was a great 


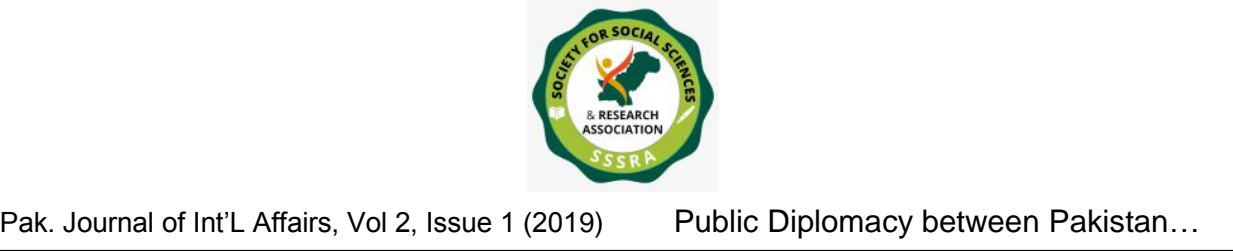

exposure of track II diplomacy in the shape of cricket diplomacy. (Talbott, Strobe, 2006).

For next three years in 2005, 2006, and 2007 cricket series were played between India and Pakistan, these series helped both the countries to ease tension. When Pakistani team did a tournament in 2005 and 2007. Pakistani cricket fans were cordially welcomed by Indian cricket lovers. It shows the love of masses of neighboring countries for each other. That era between 2004 and 2008 is considered as "the golden era" of political relations of India and Pakistan apart from the good cricket ties, unless the attack on Indian city Mumbai on 26 November 2008 which destroyed the whole time peace process. Through, cricket was not stopped even when Samjhota express train suffered a bomb attack in February 2007, in which many innocent people lost their lives, but after Mumbai attack in 2008, Indian government banned its cricket team from playing against Pakistan in India or in Pakistan.

\section{MUSHARRAF'S TOUR OF INDIA 2005}

Pervez Musharraf visited India in 2005 on the invitation of Indian PM Manmohan Singh, ice started to melt between these rival states, and both the leaders decided to open the disputed Kashmir border and soldiers were sent back to their routine position. Hence cricket diplomacy again proved to be an influential weapon between two enemy states and played vital role to bring them on a table of talks. Keeping this reality in mind, one can say with certainty that in terms of Indo-Pak friendly relations cricket has always been a key factor and has bridged the gap between rival as cricket will be played between India Pakistan. People of both the South Asian States want to see their teams playing with each other. Another positive aspect of the cricket matches is, "Keen interest of the rulers" of those two countries, in cricket. Best Nawaz Sharif and Musharraf or Vajpayee and Manmohan Singh, they all have been big fans of the game, actually Nawaz Sharif literally played club cricket. .(Rizvi, 2009.51-52)

\section{PM GILANI'S VISIT TO INDIA 2011}




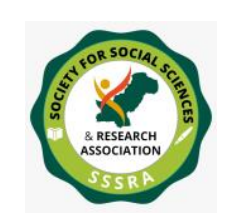

Pak. Journal of Int'L Affairs, Vol 2, Issue 1 (2019)

Public Diplomacy between Pakistan...

Next tenure of cricket diplomacy started in 2011, when PM Manmohan Singh invited PM Gilani to watch semifinal of world cup cricket between India and Pakistan. Both sat together to enjoy that On that historical occasion, Gilani also invited Singh to visit Pakistan, thus the magic of cricket diplomacy proved its significance once again. From that point peace process restarted and dialogues initiated between India and Pakistan. In result of the dialogues Pakistani cricket team went on a tour of India to play 3 ODIs and a T-20 match respectively. (Reshma Patil,2011)

\section{MODI'S MEETING WITH NAWAZ 2015}

Indian's sitting PM is not different from his predecessor in content of his passion for cricket, as he decided to meet with them PM Pakistan Nawaz Sharif a day before match between India and Pakistan, of world cup cricket in Australia 2015. This meeting created a turmoil in India media, given the tense relations between these two atomic powers those days. Indian media was not sure of the intentions of Modi's government and started discussing this meeting on the news channels. On the other hand, Pakistani electronic and print media termed this meeting, "a good will gesture from Indian PM" in order to calm things down between Pakistan and India. (Maria Saifuddin Effendi, 2016)

\section{INFERENCE OF CRICKET DIPLOMACY IN MAINTAINING PAK-INDIA TIES}

Cricket is called "The gentleman game", and this game has played a positive role in promoting the ties between Pakistan and India. This sport being favorite of Pakistani and Indian equally, has helped a lot to bring the people of both countries together. This factor can be more handy and useful if this game is played regularly on the soil of Indo-Pak. In the subcontinent one can't separate the cricket from politics, because its cricket that has huge effect on the politics of Pakistan and India.

The whole world knows that the cricket match between these two neighboring states is so crowded and thrilling that victory or defeat means a lot for Pakistanis as well as Indians. This passion and love for cricket in 


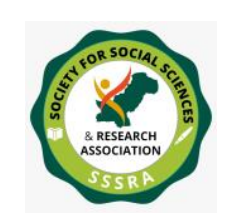

Pak. Journal of Int'L Affairs, Vol 2, Issue 1 (2019)

Public Diplomacy between Pakistan...

Indian and Pakistani can be manipulated positively so that the masses get together and get to know each other. They mingle with one another as friends as we have seen in the past, like in tour of both the teams from 2004 to 2008 .

Sports, especially cricket has been a source to establish political and social relations in the subcontinent being a very popular game. People on both sides of the border want to live with peace and harmony, so the need of the time is, that governments of Pakistan and India must resolve their dispute including Kashmir, Siachen and Sir Creek through dialogues. Cricket diplomacy should be given another chance, because this ray of light in the darkness of hated, and much awaited cricket series between Pakistan and India will bring smile on the face of Pakistanis and Indians, who are eager to see them play against each other once again in the subcontinent. (Shakeel Ahmad Shahid, 2007)

\section{CULTURAL DIPLOMACY BETWEEN PAKISTAN AND INDIA}

Pakistan and India share common values such as language, dress, seasons, customs, festivals, foods, crops etc. These values are a binding force for the public of Pakistan and India. In spite of the diplomatic differences, these common factors can help to improve the ties between the two hostile states. Though India has better statistics in terms of socio economic status but still Pakistan is not doing badly either. It is believed to be a better and fast developing country as compared to Pakistan. As far as culture is concerned Pakistan and India have a lot of similarities in music, films, theater. Cultural diplomacy has done much in favor of the peace process and is strengthening the ties between Pakistan and India. As we know that Indian movies are very popular in Pakistan and today Indian movies are being seen by everyone in Pakistan. For the past one decade or so Indian films are being shown on Pakistani cinema halls and Pakistani films in Indian cinemas. Pakistani film actors and actresses have been playing roles in Indian films likes, Fawad Khan, Ali Zafar, Meera and Veena Malik on the other hand indian actors like, Naseeruddin Shah, Om Puri, Vinod Khanna and Nandita Das have also worked in Pakistan films in the music industry. Pakistani singers perform in India, specially Rahat Fateh, Atif 


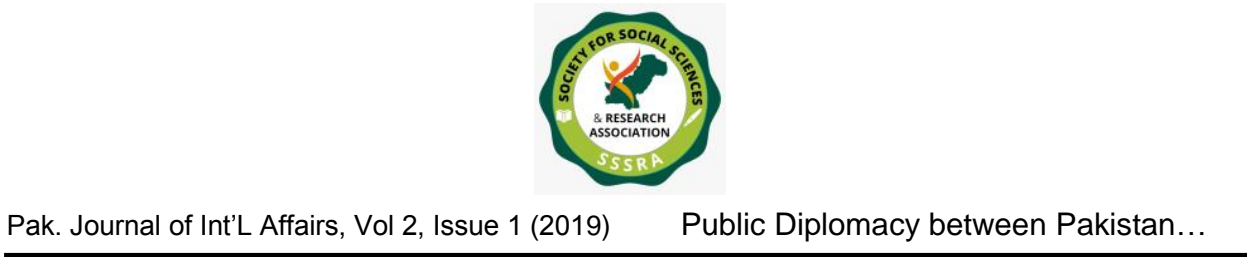

Aslam and Ali Zafar are very busy in Indian film industry and every film producer of Bollywood want them to sing songs in his movie. (Christopher Maule, 2004)

This aspect of public diplomacy is another positive act which can be practiced more regularly so that things can improve between Pakistan and India. People of both the countries love the Art and Artists and follow them in their daily life. Now this is the responsibility of Pakistani and Indian government to give visas to those artists so that they can perform in India and Pakistan without any hindrance. War is not the solution of any dispute and being the developing country Pakistan-India cannot afford to fight any kind of war. Both the states must resolve their issues through diplomacy and dialogues.

\section{MEDIA'S ROLE IN PUBLIC DIPLOMACY}

Media is assumed as the fourth pillar of a state. Be it print media, electronic media or the social media these are the resources for public to get information about country and the whole world. Pakistani and Indian media can play a vital role to keep things under control between states. If the media of Indo-Pak realize their premier duty, which is to impact genuine information rather than provocative reports, can get better. It's so rightly said that War is fought on media's battle field in current days.

Media raise the slogan of "freedom of opinions, freedom of expression and scope for progressive voices". When it comes to Pakistani and Indian media they are not playing a positive role in helping foster peace between India and Pakistan. For the last few years media has not been perusing the idea for promoting people-to-people interaction between Pakistanis and Indians. The emergence of multi-track diplomacy popularized the concept of public diplomacy through media houses enabling citizens of Pakistan and India to become ambassadors of national cultures. (Rybalko, S. \& Seltzer, T. 2010.)

Electronic and print media can play a key role in India-Pakistan peace process by functioning as an institute to promote mutual understanding, 


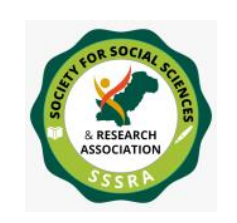

Pak. Journal of Int'L Affairs, Vol 2, Issue 1 (2019)

Public Diplomacy between Pakistan...

where citizens become students and augment their cultural knowledge, humanitarian sensitivity and acceptance of others. Unfortunately, Pakistani and Indian media houses are not showcasing the real pictures of their respective societies but they are fueling the hostile sentiments of the masses. Expect for couple of media houses that they are showing the positive images of both India and Pakistan "Geo news" is a Pakistani TV channel and "Times of India" is an Indian TV channel, they started a joint venture named "Aman $\mathrm{Ki}$ Aasha", to bring peace in the region and to spread the news of love amongst the people of the subcontinent.

Representative of the media have the power to build positive image of any country and counter the traditional views of the enemy. But in this case rather than availing this opportunity, (Aman $\mathrm{Ki}$ Aasha) journalist of subcontinent tend to remain entrapped in the web of jingoist and exclusive nationalism. As such, the media's role in public diplomacy has largely remained traditional and limited to institutionalized exchange among Indian and Pakistani journalists. Despite this negative image building by the TV channels of India. Ex cricket legend of Pakistan who is currently PM Pakistan Imran Khan visited India two to three times and, on every visit he received a very warm welcome by Indian government and Indian fans. Likewise, Indian legendary actor Om Puri (late) the Bollywood actor who visited Pakistan last year and he was given standing ovation by Pakistani audience in a TV program, he was very happy to be in Pakistan and vowed to visit Pakistan every year. It shows that media can portray a positive image of Pakistanis and Indians. An exciting development is the recent emergence of the peace media in the subcontinent. Although still this media is marginal, it has revamped the way the media operate. This is very necessary for media of Indo-Pak to neutralize the India-Pakistan discord that is so heavily dominated by enemy image, stereotypes and popular perceptions all of which are hurdles of citizen interaction and sustainable peace. (Taylor, M. \& Kent, M. L. 2010)

\section{AMAN KI ASHA: (HOPE FOR PEACE)}

Media played its role in promoting public diplomacy among Pakistan and India by starting a joint campaign by two leading media houses, The Jang 


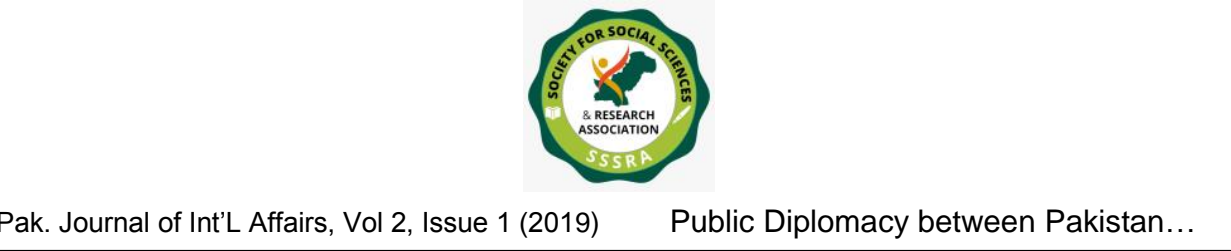

Group of Pakistan and The Times of India in India. This exciting, joint campaign aims for mutual peace and development of diplomatic and cultural relations between Pakistan and India. This joint venture proved to be very productive and fruitful and it was established on January 1, 2010. The motto behind this campaign was to launch bold, love-based people to people campaign between the children and citizens of Pakistan and India. Pakistani and Indian media houses partnered with "Friends without Borders" an international NGO and stepped up with their joint efforts after the Dil Se Dil (from heart to heart) border concert was cancelled in August 2007.

Peace efforts are the real need of the hour and only prudence between the two South Asian states, apart from foresightedness, can do wonders for Pakistan and India both. Ties between these two Atomic powers have been complex and largely hostile due to a number of historical and political events. Indo-Pak relations have been defined by the bloody and violent partition of British India back in 1947, major conflict has always been on Kashmir issue due to which numerous military collisions occurred between the two countries. Consequently, their relationship has been plagued by hostility, suspicion. For many Pakistanis and Indians "Aman Ki Aasha" is a ray of hope, to get the people of two rival states together. Despite gossips circulated by detractors targeting this peace in all kinds of underhand ways since its launch on January, 1, 2010.

In this process "Aman Ki Aasha" has provided a solid platform and a way forward for aspirations of peace between Pakistan and India.

\section{MESSAGE OF PEACE, BY PAKISTANIS AND INDIANS}

From a less privileged to a prominent citizen of Pakistan and India, want peace between these two titans. The real demonstration of this wish was seen when almost 250 prominent Pakistanis and Indians had come together to seek peace between the two neighboring countries. These citizens urged both the government through a resolution, to take all possible steps towards improving relations. The statement was initiated on May 5, 2017 and since then 250 leaders, journalist, lawyers, activists, filmmakers, 


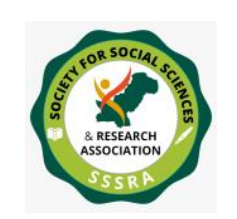

Pak. Journal of Int'L Affairs, Vol 2, Issue 1 (2019)

Public Diplomacy between Pakistan...

physicians and students have endorsed the privately shared statement. The signatories recognize the interruption of dialogue between Indo Pak due to jingoistic statements to militant attacks. (Burki, S. . J \& Akbar M, (2005).

However, they now call upon governments of both countries to engage in uninterrupted dialogue. The traditional response to such disruptions only strengthens those who want continued tensions between Pakistan and India. Calling for a peaceful subcontinent, the following are some of the demands made in the resolution;

1- $\quad$ Develop an institutionalized framework to ensure that friendly ties between India and Pakistan continue no matter what. Make dialogue uninterrupted and uninterruptible.

2- $\quad$ Ensure that political leaders, diplomats and civil servants from both countries conduct the sideline of all international and multilateral forums.

3- Recognize that the Kashmir dispute above all concerns the lives and aspirations of the Kashmir people, and work to resolve it through uninterrupted dialogue between all concerned parties.

4- Implement the 2003 ceasefire agreement between India and Pakistan.

5- $\quad$ Renounce all forms of proxy wars, state-sponsored terrorism and subversive activities against each other including through non-state actors.

6- $\quad$ Support and encourage people to people contact and remove visa restrictions and discrimination faced by citizens of both countries. This must be further taken forward to allow visa-free travel between India and Pakistan.

7- Increase trade and economic linkages and cultural exchanges between Pakistan and India.

Amongst prominent citizens those who represented Pakistan are, Kishwar Naheed (Poet), Asma Jahangir (Advocate supreme court), Afrasiab Khattak (Ex-senator), Raza Rumi (Editor daily Times), Dr. Pervez Hoodbhoy (Physicist/Teacher), Karamat Ali (Executive Director Piler), Dr Ayesha Jalal (Writer/Professor of History), Dr. Ayesha Siddiqa (scholar), Beena Sarwar (journalist), Bushra Gohar (politician/activist), Anees 


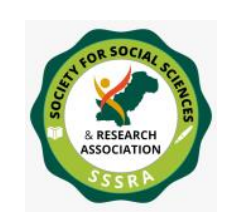

Pak. Journal of Int'L Affairs, Vol 2, Issue 1 (2019)

Public Diplomacy between Pakistan...

Haroon (activist), Jibran Nasir (Activist), Adil Najam (academician), Asma Shirazi (TV anchor), Air vice Marshal Shahzad Chaudhry, Taimur Rehman (Assistant Professor LUMS) and Naseem Zehra (Journalist, TV Anchor). Prominent citizens from India Mani Shankar AIyar (writer, former parliamentarian), Mahesh Bhatt (Film producer), Prem Shankar Jha (Journalist, columnist), Seema Mustafa (Journalist), Kamla Bhasin (activist), Kavita Krishnan (secretary All India Progressive Women's Association), Anuradha Bhasin (Co chair Pakistan and India people's Forum for Peace and Democracy), Admiral L. Ramdas (former chief of Naval staff) and Gen. Tej kaul (Executive President of India Pakistan Soldiers initiative for peace) (IPSI). It shows that not only a common citizen but prominent citizens as well of India and Pakistan want peace and harmony in the region. (Farmer. B.H.(2008)

\section{SIKHS PILGRIM VISITS TO PAKISTAN}

Pakistan is conserved the home of more than 20,000 Sikhs, actual figures are unknown though, as they have not been inducted in the recent census held in Pakistan that year. But most Sikh community are in Pakistan, says Ramesh Singh Arora, a Pakistani Sikh community leader and a member of the Pakistan Punjab National Assembly. Every year, thousands of Sikhs from Indian Punjab state visit Pakistan to observe their religious rites at the temple of Guru Nanak, who was the founder of Sikhism. The temple, Gurdwara Kartarpur Sahib marks the location where Guru Nanak lived for 17 years till he died in 1539 .

The religious tourism can bring Pakistan and India together and closer. So far, the relationship between these two states are not trustworthy. But Pakistan's Punjab province with the help of World Bank funded project is trying to change that perception. The Punjab government (Pakistan) is in move to open religious tourism at numerous Sikh, Hindu, Muslim and Buddhist sites and plans to begin spending \$50 million in January 2017 to renovate cultural and religious landmarks. Indian high commissioner to Pakistan TCA Raghaw had said in Lahore, that increased religious tourism between two neighboring states could improve relations. 


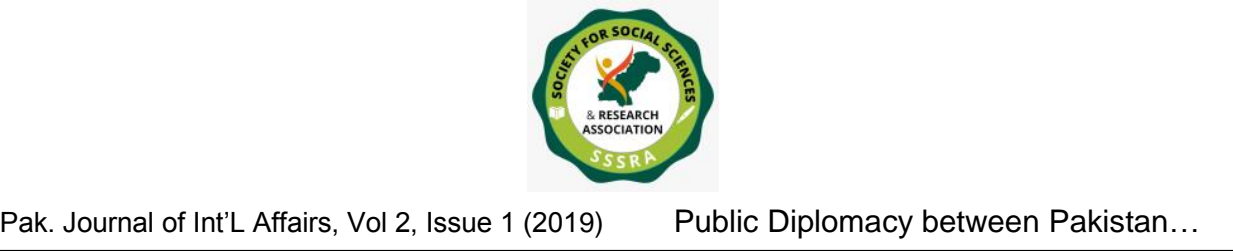

Human exchange through trade, tourism and education often referred to as people-to-people relations. This would be an economic boon to India and Pakistan and it can help resolve the core issue like Kashmir, Siachen Glacier, Sir Creek and issues on working boundary etc.

Artist teacher from India named Balwant Singh (73 year old) says he would have never left Pakistan, if he had the option seven decades ago. When British India was petitioned back in 1947 to split to two new statesPakistan and India.

\section{TRACK TWO DIPLOMACY IN THE FORM OF TREATMENT}

Despite the tense situation between Pakistan and India four month old Rohan from Pakistan underwent treatment in India, the infant from Lahore, who was suffering from a congenital heart condition. Rohan was treated at Noida Jaypee Hospital.

Rohan's father Kanwal Sadiq tweeted the external affairs Minister of India Sushma Swaraj, she responded to infant's helpless father and assured full treatment of the child in India even through the relationship between the two nations were strained. Rohan has a hole in his heart. He was suffering from D-transposition of great arteries. This required immediate medical attention as after 8 months of his birth, it can't be treated. Rohan is one of the thousand patients who have been welcomed in India for treatment. (Adil Sultan, 2014)

Sushma Swaraj showed a positive attitude towards the father of Rohan, who was helpless in Pakistan due to non-availability of treatment of his son's fatal disease. Kanwal Sadiq said in his interview to an Indian channel I thank Sushma jee from the core of my heart for issuing me Indian visa to cure my only child. In the backdrop of cross border tension between two rival states Rohan's parents were unable to get medical visa for their child's treatment in India. Thanks to Indian minister who replied with tweet that the child will not suffer. Please contact Indian High commission in Pakistan. We will give medical visa. It shows that public diplomacy can be very helpful and fruitful to normalize relations between 


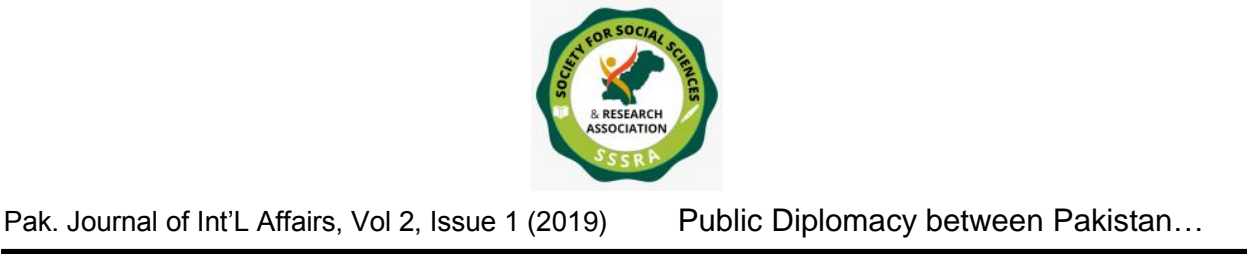

Pakistan and India, as we have witnessed in the past when cricket diplomacy, cultural diplomacy and religious visits diplomacy has proved its significance. This form of diplomacy can bridge the gaps between Pakistan and India and they should learn to live in peace and harmony with each other. This will be in good favor of both countries.

\section{CONCLUSION}

Pakistan India's relation can be different if some dispute can be ignored by both countries, as per our research it is hard to say that Pakistan India may have friendly relation in future, because they have bitter past which is neither be ignored nor be forgotten. But still war is not a solution of any dispute, in Pakistan and India's case this is highly not recommended. Because both countries are less developed countries. They must maintain diplomatic relations through sports, trade and more importantly by accepting each other, besides sharing common values and languages, still have disputes due to history and of course the Kashmir issue which is the main dispute between both states. Due to this there is no chance of any positive relations. All because before taking any positive or peaceful step towards better relations one of them grab Kashmir in that so until Kashmir remains disputed they will never have any positive diplomatic relation, but this is a need of time that both countries need to understand their importance in south Asia. 


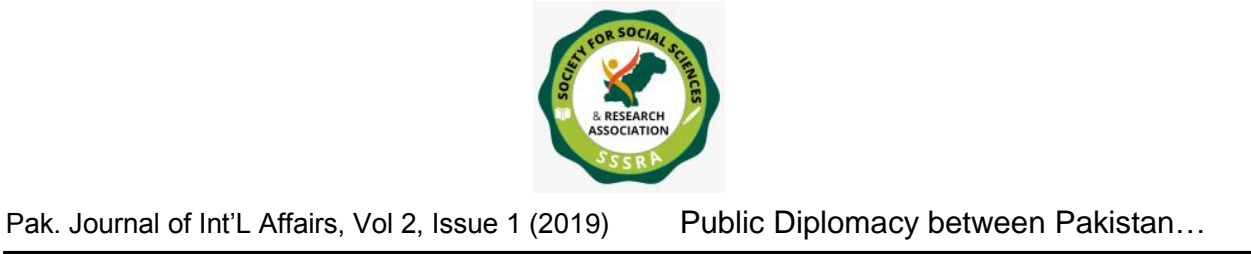

\section{REFERENCES}

Adil S. (2014). South Asian Stability- Instability Paradox: Another Perspective. IPRI Journal XIV(1), 22.

Burki, S. J. \& Akbar M. (2005). Pakistan, In South Asian Free Trade Area- Opportunities and Challenges. Washington D.C.: USAID.

Christopher Maule. (2004). Overview of Trade and Culture Conference. Ottawa: Center for Trade Policy and Law.

Effendi, M. S. \& Choudhry, I. A. India - Pakistan CBMs Since 1947 A Critical Analysis. South Asian Studies, 31(1), 187-205.

Farmer. B.H. (2008 ) Pakistan Foreign Relation with India in South Asia. Retrieved from http://thediplomat.com/2014/03/pakistan-to-grant-indiamost-favored-nation-status/ Accessed on 14-01-2015.PAKISTAN-INDIA RELATIONS: PEACE THROUGH BILATERAL TRADE. Retrieved from: https://www.researchgate.net/publication/319099932_PAKISTANINDIA_RELATIONS_PEACE_THROUGH_BILATERAL_TRADE [accessed Feb 14 2019].

Reshma Patil. (2011, May 29).BFF: Pakistan and China. Hindustan Times. Retrieved from http://www.hindustantimes.com/NewsFeed/World/BFF-Pakistan-andChina/Article1-703139.aspx.

Rizvi, M. (2009). Musharraf The Years In Power. New Dehli: Harper Collins Publishers.

Rybalko, S. \& Seltzer, T. (2010). Dialogic communication in 140 characters or less: How Fortune 500 companies engage stakeholders using Twitter. Public Relations Review 36(4), 336-341.

Shahid S. A. \& Perveen, K. (2015). Cricket for Politics and Peace; from 1987 to 2007 Cricket World Cup between India and Pakistan. International 
Journal of Science Culture and Sport (IntJSCS), 3(4) 61. http://www.iscsjournal.com/DergiPdfDetay.aspx?ID=454

Taylor, M. \& Kent, M. L. (2010). Anticipatory socialization in the use of social media in public relations: A content analysis of PRSA's Public Relations Tactics. Public Relations Review 36(3), 207-214.

Talbott, S. (2006). Engaging India: diplomacy, democracy, and the bomb. Washington, D.C.: Brookings Institution Press. 